\title{
MUSIK PENGAMEN JALANAN \\ (Studi Tentang Fungsi Musik Jalanan Sebagai Media Pendidikan Moral dan Kritik Sosial)
}

\author{
Agus Trilaksana*
}

\begin{abstract}
Abstrak
Di dalam kehidupan sosial masyarakat, musik dan pemusik jalanan adalah dua hal yang sangat menarik. Musik dapat membuat orang untuk merasa senang dan bahagia, tetapi orang juga bisa menjadi pemusik atau penyayi. Realitasnya di lapangan ternyata ada interaksi antara pemusik dan lagu-lagu yang dinyanyikan. Pada pengamen jalanan, musik dinyanyikan sekaligus mempunyai dua fungsi, yang pertama sebagai media hiburan untuk menghibur para pendengar dan yang kedua adalah sebagai sarana untuk melakukan seruan moral dan kritik sosial. Hal lainnya dalam konteks ekonomi para pemusik jalanan itu juga memperoleh uang sebagai penopang ekonominya. Jadi sekaligus sebagai strategi ekonomi untuk memperoleh pendapatan.
\end{abstract}

Kata Kunci: Musik Jalanan, Pendidikan Moral, dan Kritik Sosial.

\section{Pendahuluan}

Di dalam sejarahnya, seniman jalanan telah ada sejak lama. Di Eropa dan Amerika, bangsa pengembara, dan rumpun Slavia, yaitu suku Gipsi yang telah mengembara ratusan tahun dengan bekerja sebagai peternak, penjinak binatang pada siang hari. Pada malam hari mereka akan mermain musik, bermain boneka kayu dan mengadu nasib, meskipun tidak banyak catatan tentang kelompok ini.

Di Indonesia, khususnya di Jawa, meski seniman kraton yang mengembangkan wayang, di dalam tradisi babad ( Tanah Jawi), di ceritakan tatkala untuk menaklukan Ki Ageng Mangir, penguasa wilayah selatan, putri sulung Panembahan Senopati, Pembayun menyamar sebagai tledek, wong mbarang, yang mengembara dengan menyanyi dan menari sampai masuk ke wilayah tersebut. Karena kecantikannnya, Ki Ageng Mangir kemudian mengawini. Kisah ini berlenjut sampai akhirnya Ki Ageng Mangir bersedia menghadap
Panembahan Senapati dan dibunuh dengan membenturkan kepalanya di singgasananya, dan istrinyapun akhirnya ikut bela pati.

Pada masa kolonial, para seniman jalanan ini berkembang dalam lingkungan perkebunan. Dalam arsip kolonial tercatat bahwa Augustijn Michels, sebagai pemilik perkebunan di Citereup pada tahun 1831, diberitakan bahwa dari budak-budaknya yang berjumlah 130 orang, terdapat 30 orang budak yang menurut van de Wall disebut sebagai pemain musik yang pandai dan serba bisa (de onderscidene bekwame muzijkanten). Di samping itu, terdapat 4 orang penari ronggeng, 2 pemain gambang, dan 2 orang penari topeng. Pada waktu itu bahkan orangorang Cina juga melatih para budakbudaknya untuk menjadi artis atau pemain dalam rombongan sandiwara Cina. Budak-budak yang pandai bermain peran dalam sandiwara, menari, dan menyanyi biasanya akan dihargai dengan harga yang mahal. Gaya hidup demikian ini sebenarnya meniru budaya kraton, di mana raja juga memiliki 
sekelompok seniman, baik itu seniman tari maupun musik. Bahklan ada beberapa raja yang mempunyai kelompok seniman yang beberapa anggotanya berasal dari seniman Barat atau pemusik dari Barat, yang tinggal di kampung Musikanan sebelah Timur Pagelaran, dan di halaman dalam kraton terdapat koepel, khusus untuk bermain musik. ( Soekiman, 2000; 91). Gaya hidup yang demikian itu disebut dengan budaya indis.

Dalam perkembangan selanjutnya kemudian muncul kelompok Toniel atau stambul, seni pertunjukkan keliling dengan kisah utama diambilkan dari cerita seribu satu malam. Musik dan lagu menyertai dalam pertunjukkan tersebut. Seni pertunjukkan rakyat dengan mengambil tradisi lisan juga berkembang pula dalam kelompok kesenian tradisional Ketoprak di Jawa Tengah dan Ludruk di Jawa Timur. Meskipun alat-alat musik yang dimainkan tidak lengkap, seperti pada kelompok seni kraton, kelompok kesenian ini juga sangat banyak penggemarnya, khususnya di kalangan masyarakat bawah. Sebagai salah satu bagian dari seni pertunjukkan, maka tema cerita dalam kelompok seni tradisional ini diambilkan dari tradisi lisan, seperti cerita pahlawan lokal Sarip Tambak Oso yang dimainkan dalam pertunjukkan Ludruk. Tema cerita yang lain diambilkan dari cerita seribu satu malam dan bahkan tidak jarang juga mengadopsi cerita barat. Dalam hal ini sudah barang tentu alur ceritanya berbeda dengan tradisi kraton.

Pada saat ini musik jalanan atau musik para kelompok masyarakat bawah juga berkembang dengan cara yang agak unik. Musik jalanan sudah tidak lagi identik dengan seni pertunjukkan yang dimainkan oleh banyak orang dengan membentuk kelompok kesenian tertentu, semacam Ketoprak Siswo Budaya ataupun Kesenian Ludruk Enggal Tresna pada dekade 1980-an. Pada saat ini musik jalanan bisa tampil sendiri, seperti musik sinteran yang bisa dimainkan oleh satu orang atau dua orang. Seorang memainkan musik sinter dan yang lainnya nembang, menyanyikan gending jawa atau sambil memainkan musik sinter ia menyanyi. Alat musik sinter merupakan modifikasi alat musik Cina yang berupa kotak kayu sebagai wadah resonansi dengan banyak dawai. Cara memainkan dengan meletakan sinter secara mendatar dan dipetik dengan kedua tangan.

Pada saat ini pada umumnya terdapat dua kelompok pemusik jalanan, yang pertama adalah para pemusik lama (pemusik tradisional), dengan alat musik sinter, gitar atau tayub dengan menyanyikan lagu-lagu jawa dan keroncong. Kelompok kedua adalah para pemusik jalanan atau para pengamen dengan rentang usia yang bervariasi mulai dari yang masih anakanak sampai dewasa. Mereka melakukan kegiatan bermusiknya di berbagai tempat, mulai di perempatan jalan saat lampu merah, ada yang menyanyi di kendaraan umum, biasanya dilakukan di dalam bus kota atau bus antar kota, dan ada juga yang menyanyi dari rumah ke rumah. Alat musik yang dipakai-pun juga mulai dari yang paling sederhana, kecek-kecek buatan sendiri dari sejumlah tutup botol yang dipaku pada kayu yang kemudian di goyanggoyangkan, ada alat yang terbuat dari botol plastik sedang yang di isi dengan beras, sampai pada gitar dan juga tetabuhan dari galon air minum. Para pemusik kebanyakan hanya mengandalkan suara saja, meskipun ada sebagian yang menggunakan alat soundsystem sebagai pengeras suara dengan memakai sumber energi dari baterai atau aki.

Terlepas dari variasi tersebut hal yang sangat menarik adalah lagulagu yang dinyanyikan oleh para pengamen tersebut. Mereka ternyata 
sering membawakan lagu-lagu yang telah dirubah syairnya dengan tujuan untuk melakukan kritikan terhadap kondisi sosial dan moral yang ada dalam masyarakatnya. Oleh karena itu dalam tulisan ini permasalahan yang ingin pendidikan moral dan kritik sosial?

\section{Pembahasan}

\section{Seni Sebagai Eksistensi Diri}

Rasa keindahan yang terwujud dalam seni merupakan bagain dari eksistensi diri akan kehidupan manusia yang selalu digerakkan oleh empat nilai dasar. Salah satunya adalah dunia material, dengan tanpa mengejar keuntungan karena kenikmatan hadirnya sebuah obyek keindahan. Oleh Thomas Aquinas, keindahan disebut sebgai "id quod visum placet" yang menyenangkan unutk pandang. Ketiga nilai lainnya menurut Le Senne, seorang filsuf eksistensialisme dari Prancis adalah, pertama, nilai yang mengarah pada dunia material, tetapi tanpa mengejar keuntungan ekonomi, karena adanya kenikmatan akal budi atau kebenaran, kedua, nilai yang mengatasi dunia material, mengatur terhadap kelakukan manusia agar mencapai kehidupan masyarakat yang teratur, tertib dan abadi, dan ketiga, nilai yang mengatasi dunia material, mancari hakekat diri sendiri tanpa egoisme apapaun atau nilai-nilai kerohanian dan ketuhanan ( Hartoko, 1993:9).

Dengan demikian, kesenian tidak saja selalu melukiskan sebuah unsur atau aspek alam kodrat ditambah tanggapan atau pengolahan manusia. Yang indah harus didefinisikan dengan apa yang ketika dilihat atau didengar dinilai sebagai yang baik. Keindahan membawa serta ekspansi rasa hidup dan kesadaran diri sebagai bagian dari keseluruhan. Sifat sosial dari kesenian adalah meratakan pengalaman dan perasaan seseorang seniman kepada dicermati adalah (1) Tema musik apakah yang dinyanyikan oleh para pemusik pengamen jalanan?, (2) Bagaimana para pemusik jalanan itu menjadikan lagu atau syair yang dinyanyikannya sebagai media

orang lain yang dengan kesenian itu akan dapat memanusiakan diri lebih sempurna. Menurut Plato, melihat keindahan itu tidak lebih dari tiruan alam secara subyektif dan individual, tetapi menurut Aristoteles, keindahan dalam berkesenian adalah suatu perwujudan daya cipta manusia yang spesifik. Fungsinya adalah untuk mengidealisasikan dan menguniversalkan kebenaran, sehingga kebenaran itu menghibur hati dan menanamkan cita-cita mulia lebih dari keyakinan rasional belaka.( Blakker, 1990; 46-47)

Oleh karena itu, menurut Williem Bascom ( 1965), seni tradisional merupakan bagaian dari folklor yang berfungsi sebagai sistem proyeksi, yaitu (a) sebagai alat pencerminan angan-angan suatu kolektif, (b)sebagai alat untuk pengesahan pranata-pranata dan lembaga-lembaga kebudayaan, (c) sebagai alat pendidikan, dan (d) sebagai alat pemaksa dan pengawas agar norma-norma masyarakat akan sesalu dipatuhi anggota kolektifnya. Menurut Betty Wang, seni sebagai folklor juga berfungsi untuk melakukan kritik atau protes sosial, maka dalam hal ini beberapa Kaisar Tiongkok kuno, seperti Kaisar Yui dari dinasti Hsia dan Kaisar Chow Wen Whang dari Dinasti Chow mempunyai staf khusus yang tugasnya mengumpulkan nyanyian rakyat yang dinyanyikan di warung-warung teh di wilayah kerajaannya. Koleksi itu akan dipelajari isinya, karena dari isi lagu rakyat di warung-warung tersebut raja akan dapat mengetahui pendapat rakyat 
terhadap kebijaksanaannya dalan menjalankan roda pemerintahan Danandjaya, 1984;18-19)

$$
\text { Seni adalah cermin }
$$

masyarakatnya. Dalam konteks demikian, seni dilihat sebagai cermin dari kondisi sosial yang dialami masyarakat. Seni juga mengekspresikan persoalan yang dihadapi oleh masyarakat pada zamannya yang merupakan produk dari kepekaan sang pencipta seni itu terhadap kondisi sosial yang berkembang dalam masyarakatnya. Dengan demikian, seni tidak hanya mengekspresikan rasa keindahan manusia, melainkan juga menpunyai fungsi sosial, seperti melakukan kritik sosial terhadap keadaan masyarakat yang penuh dengan ketidak adilan, ketimpangan, demoralisasi, dan sebagainya. Melalui syair lagu-lagu, mereka para seniman melakukan kritik sosial terhadap kondisi masyarakat dan juga sekaligus menyapaikan pesan moral kepada masyarakat bahkan kepada penguasa.

Secara ekonomi para pemusik jalanan atau pengamen jalanan adalah berasal dari masyarakat strata bawah. Mereka menjadi pemusik jalanan kerena lebih didorong oleh kondisi kehidupannya yang termarjinalkan. Mereka adalah orang-orang yang kalah ketika memasuki arena kompetisi, yang menurut mereka jelas tidak memberikan keadilan sosial, bahkan diarena kompetisi itu mereka mengalami ketidakadilan, seperti ditertibkan, digaruk dan lain sebagainya, oleh aparat birokrasi maupun oleh aparatur negara. Ibaratkan di arena pertandingan sepakbola, dalam perebutan ruang dan kesempatan hidup, negara yang seharusnya menjadi wasit yang adil, justru melakukan keberpihakan kepada yang kuat, dan keputusannya sering mengalahkan pihak yang lemah, seperti pedagang asongan, pedagang kaki lima dan para pemusik jalanan.
Bagi pemusik jalanan dengan mengalami kondisi kehidupan sosial yang demikian tidak adil tersebut, maka sebagai pemusik jalanan mereka tidak hanya sekedar untuk mencari sedikit nafkah hidup di tengah kondisi yang serba sulit. Musik jalanan juga sekaligus mereka pergunakan sebagai saluran untuk mengaktualisasikan diri dan juga untuk mengekspresikan kondisi kehidupan yang mereka alami seharihari.

\section{Musik Jalanan Sebagai Media Pendidikan Moral dan Kritik Sosial}

Bagi sebagian masyarakat, berkesenian mempunyai tujuan untuk memenuhi kebutuhan akan rasa keindahan, sebagian masyarakat lainnya berkesenian selain untuk memenuhi rasa keindahan juga bisa untuk memenuhi kebutuhan yang sifatnya material, bahkan dapat dipakai untuk mengekspresikan rasa ketidakadilan, kekecewaan, dan kesenjangan serta demoralisasi masyarakatnya. Alasan subyektif orang memenuhi kebutuhan rasa keindahan yang bersifat nonmaterial lebih bersifat rekreatif, yang dalam bahasa Max Weber ( dalam Ritzer, 1996; 34) disebut dengan tindakan sosial afektual. Namun ketika orang berkesenian untuk memenuhi kebutuhan material, berkesenian seperti itu lebih bersifat rasional instrumental. Berkesenian yang bertujuan untuk melakukan kontrol sosial, kritik sosial dan untuk menyuarakan seruan moral atau bahkan protes sosial lebih merupakan tindakan berkesenian yang lebih bersifat rasionalitas nilai.

Pandangan seperti itu justru merupakan antitesis dari pandangan Karl Marx, yang berpandangan bahwa berkesenian adalah merupakan bagian dari suprastruktur yang lebih menjamin kepada para pemilik modal. Bagi para pemilik modal, dunia kesenian diposisikan sebagai instrumen untuk 
memperoleh keuntungan, misalnya yang terjadi di jagad hiburan musik di Indonesia. Di balik gemerlapnya dunia hiburan musik di Indonesia, para pemilik modal memperoleh keuntungan yang sangat besar.

Dalam konteks musik jalanan, para pemusik jalanan mencoba mengkaitkan kondisi obyektif dan kondisi subyektif kehidupannya dengan substansi syair-syair lagu yang mereka ciptakan dan mainkan. Kondisi obyektif dan subyektif tersebut mereka ekspresikan melalui rangkaian simbolsimbol yang mempunyai makna dalam lagu-lagunya. Dalam posisi demikian para pemusik jalanan pemposisikan keseniannya tidak hanya sebagai sarana penghibur diri untuk memenuhi kebutuhan yang sifatnya material. Para pemusik jalanan justru menggunakan musik jalanan yang mereka ciptakan dan nyanyikan sebagai sarana untuk kritik sosial dan penyampaian moral. Melalui syair-syair lagu yang mereka ciptakan, keseniannya diposisikan sebagai media yang cukup ampuh untuk mengekspresikan diri untuk melakukan kontrol sosial, kritik sosial, penyampai moral kebaikan, bahkan protes sosial secara halus. Mereka melalui lagu-lagu yang dinyanyikan melakukan protes terhadap tingkah polah aparatur birokrasi dan negara yang sering secara represif melakukan tindakan ketidakadilan, penindasan, perampasan hak, penggusuran yang dilakukan terhadap rakyat lapisan bawah.

Kritik sosial atau protes sosial, biasanya dihubungkan dengan perlunya suatu situasi ideal dan perilaku ideal (ideal conduct). Apabila suatu ktritik sosial ditujukan kepada elite penguasa, maka biasanya yang dipermasalahkan adalah tidak adanya standart yang cukup baik dari perilaku aparatur atau pelaksanaan dan fungsinya berdasarkan ethis dan moralitas yang tinggi, sebagaimana yang diharapkan oleh masyarakat luas dari elite atas. Ethos dan moralitas ini bukan dinilai sebagai sesuatu yang hanya berdasar emosional dan irasional, melainkan justru harus bersama dan berdasarkan pengetahuan tentang masyarakat. Kritik sosial itu kemudian biasanya dinilai sebagai barometer sosial politik masyarakat. Adanya pendapat-pendapat yang menginginkan koreksi, perbaikan, perubahan nilai dan sistem nilai yang bersifat persuasif. ( Susanto, 1977;14). Dengan demikian kritik sosial itu berfungsi sebagai kontrol sosial untuk mengawasi fungsi-fungsi lembaga sosial dan politik yang tidak berjalan dengan semestinya.

Oleh karena itu, pada dasarnya pada setiap angkatan atau zaman akan menghasilkan produk seni atau sastra yang mengandung kritik sosial terhadap ketimpangan yang terjadi dalam kehidupan masyarakat. Seni pada hakekatnya adalah sebagai cermin masyarakatnya. Seni mencerminkan persoalan sosial yang ada dalam masyarakatnya dan kalau penciptanya memunyai kepekaan tinggi, maka karyanya pasti juga mencerminkan kritik sosial yang ( barangkali tersembunyi) ada dalam masyarakatnya ( Darmono, 1977; 61) Hal yang sama juga akan terjadi dalam kesenian yang lain, misalnya dalam kesenian teater rakyat juga merupakan sarana untuk melakukan kritik sosial ( Danandjaya, 1983; 87)

Oleh karena itu ketika kondisi masyarakat, bangsa dan negara penuh dengan korupsi, kolusi, nepotisme dan kemerosotan moral maka banyak produk seni yang mengekspresikan kondisi sosial masyarakat seperti itu. Para pemusik jalanan juga menggunakan syair-syair lagu yang mereka ciptakan dan nyanyikan untuk melakukan kritik sosial terhadap maraknya budaya KKN ( Korupsi, Kolusi dan Nepotisme) tersebut. Bahkan banyak juga kebijakan-kebijakan suprastruktur yang lebih memihak 
kepada pemilik modal daripada masyarakat bawah. Melalui lagu-lagu yang mereka ciptakan mereka juga mengungkapkan apa yang mereka alami dan apa yang mereka inginkan tentang terciptanya masyarakat yang ideal.

Bagi para pemusik jalanan, melalui syair lagu, masyarakat yang ideal adalah masyarakat yang dicirikan oleh adanya kemerdekaan dalam semua aspek kehidupan. Kondisi negara yang warga negaranya memepunyai kebebasan berpendapat, kebebasan berserikat, bebas dari rasa takut, bebas dari penindasan, bebas dari penggusuran, bebas dari garukan, bebas dari polah tingkah aparatur yang represif dan juga yang paling utama bebas dari kemiskinan. Melalui syair lagu-lagu yang dinyanyikan para pemusik jalanan itu uga mengekspresikan preferensi dari negara yang demokrasi dan merdeka. Mereka menyebut dengan orde babi untuk menggambarkan protes mereka terhadap pemerintah yang tidak berani menangkap dan mengadili para koruptor.

Karl Marx menteorikan bahwa aparatur birokrasi dan aparatur represif negara merupakan bagian dari suprastruktur yang tidak menggambarkan negara yang demokratis dan merdeka. Bahkan Marx mengatakan bahwa birokrasi dan militer mempunyai kepentingan sendiri. Dalam tataran empirik banyak dijumpai fenomena aparatur birokrat dan militer yang menjadi instrumen bagi para pemilik modal untuk menjamin kepentingan-kepetingannya, seperti kasus penggusuran perkampungan kumuh, penertiban PKL dan penindasan buruh bahkan obrakan para pengamen jalanan sendiri. Mereka tidak pernah membela kepentingan kaum lemah, kelas proletar, seperti yang tersirat dalam syair lagu pemusik jalanan berikut ini;

\section{Pedagang Asongan}

Kejar mengejar jadi tontonan

Antara kamtib dan pedagang asongan

Pedagang asongan diburu bagai buronan

Tragedi ini terjadi di negeri ini

Malu dong sama bumi pertiwi

Pedagang asongan dirampas

Sungguh malangkah mereka

Becak digusuri, jadi kapalkah becaknya

Tunjukkanlah yang benar pada kami..........generasi nanti

Jangan main sikut....jangan main tendang

Kalau ingin perut kenyang

Jangan main gusur kalau ingin hidup makmur

yang jadi pejabat....jadilah pejabat

Asal jangan suka sikat uang rakyat

Yang jadi polisi...jadilah polisi

Asal jangan main sikat sembarangan

Yang jadi pak hasip..jadilah pak hansip

Asal jangan suka mengintip

Yang jadi Pak Lurah....jadilah Pak Lurah

Ngurus KTP, yang biasa saja

Yang jadi Abri....jadilah Abri

Asal jangan suka pukul rakyat pribumi. 
Pada tataran teoritik, aparatur birokrasi dalam menjalankan fungsinya harus tunduk pada peraturan perundangan yang berlaku, kewenangan yang jelas, dan bahkan harus ada pemisahan yang jelas antara pemilikan yang pribadi dan publik. Pemisahan itu tujuannya untuk menghindari penyalahgunaan wewenang dan korupsi. Namun pada tataran empirik seringkali aparatur birokrasi dalam manjalankan peran dan fungsinya tidak bisa membedakan antara kepemilikan pribadi dan publik, misalnya mobil dinas dipakai untuk kepentingan pribadi pada masa liburan bukan untuk keperluan tugas dinas. Dalam pemberitaan di media massa setiap hari kita disuguhi dengan banyaknya pejabat negara, baik dalam lingkup eksekutif, legislatif dan juga

\section{Tiang Negara}

\section{Kau tahu}

Rayap-rayap makin banyak

Dimana-mana

Di balik baju resmi

Menggerogoti tiang negara

Kau tahu

Babi-babi makin gemuk negeri ini

Mereka dengan tenang

Memakan desa dan kota

Rayap-rayap yang ganas merayap

Berjas dasi dalam kantor

Dengan menyimak lagu di atas, para pengamen jalanan mengkritisi bahwa di negeri ini telah banyak para aparatur nagara, yang berjas dan berdasi dalam kantor yang berperan sebagai rayaprayap yang ganas menggerogoti darah rakyat. Mereka tak peduli dengan kondisi kehidupan rakyat, terus berkembang biak dengan hanya menggemukkan diri sendiri dan kelompoknya. Mereka menggencet rakyat dan menghancurkan tata yudikatif yang melakukan korupsi. Bahkan, mafia kasus dan mafia hukum telah bergentayangan di mana-mana, korupsi meluas dari level atas sampai bawah.

Untuk menggambarkan kondisi tersebut para pemusik jalanan menciptakan lagu Tiang Negara untuk melukiskan para aparatur yang korup tersebut sebagai rayap dan babi. Dalam syair lagu itu jelas sekali berisi mengenai pendidikan moral atau pesan moral bagi setiap pejabat di negaeri ini untuk tidak melakukan tindakan korupsi, yang hanya memperkaya diri sendiri dengan menghisap darah rakyat. Para pejabat janganlah jadi penghisap uang rakyat dengan berbaju resmi birokrat yang justru menggerogoti Tiang Negara.

Makan minum darah rakyat

Babi-babi yang gemuk sekali

Tenang- tentram berkembang biak

Tak ada yang peduli

Mengemuk para babi

Lautan sawah dan hutan

Menggencet anak rakyat

Meremas jantung mereka

Merayap para rayap

Dalam bumi yang kian rapuh

Puaslah tipu rakyat

Terbantai tanpa ampun

kehidupan rakyat dengan sepuasnya menipu rakyat.

Bagi rakyat kecil, demokrasi adalah simbol dari kebebasan, kebenaran dan keadilan. Demokrasi adalah adanya jaminan bagi setiap warga negara untuk bebas berpendapat, bebas dari politik yang totaliter dan bebas dari penjajahan oleh bangsa sendiri. Melalui syair lagu Kemerdekaan dan Turun ke Jalan, para pemusik jalanan melalui 
gagasannya mengajukan kritik sosial terhadap kehidupan demokrasi di negara merdeka Indonesia yang masih jauh dari harapan. Masyarakat dipandangnya masih terbelenggu oleh penindasan, pencekalan, tidak bebas menyatakan pendapat, penuh rasa takut dan penuh dengan represi pemerintah. Kondisi tersebut tentu sangat bertolak belakang dengan pandangan Max Weber yang menyatakan "bahwa politik adalah tugas jabatan dan panggilan hidup untuk itu harus amanah dan mementingkan kepentingan rakyat. Sejalan dengan itu Imanuel Kant juga mengingatkan agar para politikus atau pejabat harus bertingkah laku sebagai politikus moralis, yaitu seorang politikus atau pejabat yang selalu mengedepankan moralitas dalam menjalankan tugasnya, bukan sebaliknya sebagai moralis politik, yaitu yang selalu mereka-reka moralitas untuk kepentingannya sendiri. ( Toto Sugiarto, dalam Kompas Edisi 18 Juni 2005)

\section{Kemerdekaan}

Kemerdekaan untuk berbicara
Harus kita rebut
Karena berbicara adalah hak azasi
Untuk berbicara dilindungi konstitusi
Kami menentang penggusuran
Kami menentang pencekalan
Kami menentang penindasan
Karena ini negara merdeka
Bukan negara yang dijajah
Karena ini negara demokrasi
Bukan negara otoriter
Mari bersama bikin organisasi
Mari bersatu galang kekuatan
Kita bikin tuntutan
Dengan turun ke jalan
Tegakkan kebenaran
Tegakkan keadilan

Menganalisi isi syair lagu Kemerdekaam tersebut, berarti bahwa kemerdekaan berbicara harus diperjuangkan kalau perlu direbut, karena kebebasan berbicara adalah hak azasi yang dilindungi oleh UUD 1945. Mereka juga menentang adanya penggusuran, pencekalan, dan penindasan karena Indonesia adalah negara merdeka, bukan negara jajahan,
Indonesia adalah negara demokrasi bukan negara otoriter. Kalau negara atau aparatur negara bersikap anti demokrasi dan bertindak sewenangwenang maka kita harus bersartu padu turun ke jalan memperjuangkan kebenaran dan keadilan, seperti yang tersirat dalam syair lagu pengamen jalanan berikut ini;

\section{Turun ke Jalan}

Mari kita bergandeng tangan

Tuk menggalang kekuatan

Dengan turun ke jalan 
Mari kita kepalkan tangan

Tuk lontarkan perlawanan

Terus maju ke depan

Mari kita acungkan tangan

Tuk teriakan

Segala tuntutan perubahan

Rakyat pasti menang

Karena kemerdekaan

Adalah jiwa kita

Mengenyahkan penindasan

Karena keadilan

Adalah nurani kita

Rakyat pasti menang

Karena kemerdekaan adalah jiwa kita

Karena keadilan adalah nurani kita.

Dalam mengkritisi kondisi kehidupan sosial ekonomi para pemusik jalanan juga mempunyai syair lagu agar setiap manusia bersyukur atas karunia nikmat yang diberikan oleh Tuhan kepada manusia, tidak usah merasa iri atas rezeki orang lain, harus bersikap rendah hati dan tidak sombong kalau hidupnya lagi banyak rezeki, mempunyai sifat dermawan, saling berbagi karena kalau meninggal harta dunia tidak dibawa, seperti yang nampak dalam syair lagu jawa sebagai berikut.

\section{Wong Urip}

Aja ngece karo wong ora nduwe

Donya banda yen mati ora digawa

Paribasan urip kaya wong mampir ngombe

Iku ngono jare simbahku dewe

Yen numpak sepur asepe metu nduwur

Urip ajur mumur yen ora diatur

Yen numpak becak asepe metu telak

Aja ngguyu ngakak yen urip lagi kepenak

Yen numpak motor asepe metu ngisor

Wongu urip iku kudu isa andap asor

(Dalam bahasa Indonesia)

Jangan menghina dengan orang yang tidak punya

Harta benda itu kalau mati tidak dibawa

Peribahasanya, hidup itu seperti orang yang numpang minum

Itu katanya kakekku sendiri

Kalau naik kereta api itu asapnya keluar melalui atas

Hidup itu bisa hancur kalau tidak diatur

Kalau naik becak itu asapnya keluar melalui tenggorokan

Jangan tertawa terbahak-bahak kalau hidup lagi enak

Kalau naik motor itu asapnya keluar lewat bawah

Orang hidup itu harus bersikap rendah hati 


\section{Simpulan}

Dalam realitas sosial, kesenian dalam hal ini adalah musik memang tidak hanya berfungsi sebagai ekspresi atas keindahan tetapi juga berfungsi sebagai ekspresi rasa ketidakadilan, kekecewaan dan kesenjangan yang mereka alami. Seni memang pada dasarnya adalah cermin realitas masyarakatnya. Demikian juga dengan musik pengamen jalanan, yang syairsyairnya selalu berisi cerminan dari kondisi obyektif dan subyektif dari pengamen itu sendiri. Mereka memotret kondisi obyektif masyarakatnya dengan berbagai syair lagu dengan tema kritik sosial, ketimpangan, dan juga kekuasan yang otoriter dari aparat, seperti

\section{Daftar Pustaka}

Bakker ,JW, 1990, Filsafat Kebudayaan Suatu Pengantar, Jakarta : Kanisius

Cassier, Ernst, 1987, Manusia dan Kebudayaan, Sebuah Esai Tentang Manusia, Jakarta: Gramedia.

Danadjaya, James, 1983, Seni Dalam Masyarakat Indonesia. Jakarta: Gramedia Pustaka 1984, Folklor Indonesia, Ilmu Gosip, Dongeng dan lain-lain. Jakarta.: Grafiti Pers.

Darmono, Sapardi Djoko, 1977, Kritik Sosial Dalam Sastra yang ada dalam lagu dengan judul Pedagang Asongan, Tiang Negara, Kemerdekaan, Turun ke Jalan. Mereka juga mengekspresikan kehidupan subyektifnya yang serba susah, harus sabar, tidak usah iri dengan rezeki orang lain dalam lagu Wong Urip. Dengan demikian, melalui karya lagulagu dari para pemusik jalanan atau pengamen jalanan ini sebenarnya kita bisa melihat potret sesunguhnya dari realitas sebagaian besar masyarakat Indonesia sebagai bangsa yang merdeka. Bangsa yang telah merdeka, sekali lagi telah merdeka, namun secara substansial banyak diantara rakyat ini yang belum merasakan arti dari kemerdekaan itu yang sebenarnya.

Indonesia. Prisma No 10 Tahun VI.

Murray, Alison, 1992, Budaya Kampung dan Elok Radikal di Jakarta, Prisma. No.5 Tahun XXI

Ritzer, George, 1996, Sosiologycal Theory. Fourth Edition, Toronto: The McGraw Hill. Co Inc.

Soekiman, Djoko, 2000, Kebudayaan Indis dan Gaya Hidup Masyarakat Pendukungnya di Jawa. Yogyakarta: Bentang Budaya.

Sugiarto, Toto, Politikus Moralis dan Moralis Politikus, Dalam Kompas Edisi 18 Juni 2005. 
